\title{
Casein Kinase 2 Inhibitor, CX-4945, as a Potential Targeted Anticancer Agent in Gastric Cancer
}

\author{
HYUN MYONG KIM ${ }^{1,2}$, INHYE JEONG ${ }^{1,2}$, HYUN JEONG KIM ${ }^{1,2}$, SUN KYOUNG KANG ${ }^{2}$, \\ WOO SUN KWON ${ }^{2}$, TAE SOO KIM ${ }^{2}$, KYU HYUN PARK $^{2}$, MINKYU JUNG ${ }^{3}$, \\ JOHN SOONG ${ }^{4}$, SHU-CHUAN LIN ${ }^{5}$, HYUN CHEOL CHUNG ${ }^{1,2,3}$ and SUN YOUNG RHA ${ }^{1,2,3}$ \\ ${ }^{1}$ Brain Korea 21 PLUS Project for Medical Science, Yonsei University \\ College of Medicine, Seoul, Republic of Korea; \\ ${ }^{2}$ Songdang Institute for Cancer Research, Yonsei University College of Medicine, Seoul, Republic of Korea; \\ ${ }^{3}$ Division of Medical Oncology, Department of Internal Medicine, Yonsei Cancer Center, \\ Yonsei University College of Medicine, Seoul, Republic of Korea; \\ ${ }^{4}$ Senhwa Biosciences Corporation, San Diego, CA, U.S.A.; \\ ${ }^{5}$ Senhwa Biosciences, Inc., New Taipei City, Taiwan, R.O.C.
}

\begin{abstract}
Background/Aim: Casein kinase 2 (CK2) is involved in multiple cellular processes. Furthermore, its overexpression in several human cancers has been associated with tumor progression. In this study, we evaluated the efficacy of the CK2 inhibitor, CX-4945, in gastric cancer cell lines and explored the potential predictive biomarkers for CX-4945 sensitivity. Materials and Methods: The sensitivity to CX-4945 was screened in 49 gastric cancer cell lines by the MTT assay. The mRNA and protein expression of CK2 subunits ( $\alpha$ and $\alpha^{\prime}$ ) were determined using $q R T-P C R$ and western blot. Furthermore, the activity of $C K 2 \alpha$ was measured by ELISA. Gene expression and mutations were analyzed via whole-exome and RNA sequencing. Results: The sensitivity to CX-4945 was determined by the inhibition rate (\%) at the effective dose $(10 \mu \mathrm{M})$ which ranged from $-1 \%$ to $89 \%$ in 49 gastric cancer cell lines. CK2 $\alpha$ ', but not CK2 $\alpha$, mRNA expression was correlated with CX-4945 sensitivity. Conclusion: In this study, CX-4945 showed modest antitumor efficacy in gastric cancer cell lines. CK2 might represent a potential therapeutic target for gastric cancer.
\end{abstract}

Correspondence to: Sun Young Rha, MD, Ph.D., Songdang Institute for Cancer Research, Division of Medical Oncology, Department of Internal Medicine, Yonsei Cancer Center, Yonsei University College of Medicine, 50-1 Yonsei-Ro, Seodaemun-Gu, Seoul 03722, Republic of Korea. Tel: +82-2-2228-8053, Fax: +82 23625592, e-mail: RHA7655@yuhs.ac

Key Words: Casein kinase 2, gastric cancer, CX-4945, biomarker, targeted agent.
Gastric cancer is the most commonly diagnosed cancer in Korea and increased annual screenings indicated that the proportion of early gastric cancer increased to $73.6 \%$ of all cancer cases (1). Based on a Korea National Cancer Incidence Database (KNCI DB), gastric cancer is the second $(15.2 \%)$ and third (9.5\%) highest in males and females, respectively. Also, gastric cancer recorded as the forth (9.2\%) and sixth (7.9\%) highest cause of death in males and females, respectively (2). In America and Europe gastric cancer burden remains high (3). Several agents have been developed to treat metastatic gastric cancer including those targeting the epidermal growth factor receptor (EGFR), human epidermal growth factor receptor 2 (HER2), vascular endothelial growth factor (VEGF) and hepatocyte growth factor receptor (HGFR/C-Met). However, except for trastuzumab and ramucirumab, most of them have failed to show efficacy in gastric cancer (4-6). A comprehensive understanding of gastric cancer biology is needed for new drug development $(7,8)$.

Casein kinase 2 (CK2) is a serine/threonine kinase that is a tetramer of two catalytic subunits $\alpha$ and $\alpha$, and a regulatory subunit $\beta$. CK2 plays a critical role in multiple cellular processes such as DNA repair, maintenance of cell viability, protection of cells from apoptosis, and cell-cycle regulation $(9,10)$. Dysregulation of CK2 plays an important role in cancer progression via regulation of signal transduction pathways, including PI3K/AKT and the MAPK pathway (11, 12). CK $2 \alpha$ phosphorylates $\mathrm{p} 53 / \mathrm{p} 21$ and increases $\mathrm{C}$-myc, which regulates tumor progression. Furthermore, CK2 $\alpha$ overexpression is associated with epithelial-mesenchymal transition (EMT) (13). CK2 overexpression is also correlated with poor prognosis in various cancer types $(14,15)$. In gastric 
cancer, CK2 activates DNA repair pathways induced by chemotherapeutic drugs and makes cells resistant to DNAdamaging agents (16). Also, CK2 expression is related with the progression of gastric cancer and poor survival of gastric cancer patients, suggesting that $\mathrm{CK} 2$ regulates carcinogenesis (17). However, the status and role of CK2 in gastric cancer has not been extensively studied.

CX-4945 is a selective and ATP-competitive inhibitor of both catalytic subunits CK2 $\alpha$ and CK2 $\alpha^{\prime}$ (18). CX-4945 has demonstrated an antitumor effect via suppressing signal transduction pathways, DNA repair, cell cycle arrest and induction of apoptosis by decreasing CK2 expression in various tumors $(19,20)$. Phase I/II studies have been conducted to evaluate antitumor efficacy and safety in human cancers including cholangiocarcinoma (21). However, the functional correlation of CK2 and CX-4945 in gastric cancer remains unknown. Therefore, we evaluated CX-4945 efficacy in relation to $\mathrm{CK} 2$ status in an effort to provide a new treatment strategy for gastric cancer.

\section{Materials and Methods}

Cell lines. Forty-nine human gastric cancer cells were used in this study. Four cell lines were obtained from the ATCC (American Type Culture Collection, Rockville, MD, USA), 11 cell lines were obtained from the Korean Cell Line Bank (Seoul, Republic of Korea), 9 cell lines were purchased from the JCRB Cell Bank (Japanese Collection of Research Bioresources Cell Bank, Osaka, Japan), and 25 cell lines were established by the CMRC (Cancer Metastasis Research Center, Yonsei University College of Medicine, Seoul, Korea) from metastatic gastric cancer patients $(22,23)$. Cell lines were cultured in Eagle's Minimum Essential Medium (EMEM), RPMI-1640 containing 10\% fetal bovine serum (Lonza, Basel, Switzerland), 100 units $/ \mathrm{ml}$ penicillin, and $100 \mu \mathrm{g} / \mathrm{ml}$ streptomycin (Lonza, Basel, Switzerland). Cultured cells were incubated at $37^{\circ} \mathrm{C}$ with $5 \% \mathrm{CO}_{2}$.

Cell viability assay. Cells $\left(8 \times 10^{3}\right)$ were seeded into 96 -well plates. After 24 h, CX-4945 (Senhwa Biosciences, Inc., New Taipei City, Taiwan, R.O.C) was applied at $0.1,1,5,10$ or $20 \mu \mathrm{M}$ concentrations. Following $72 \mathrm{~h}$ of incubation, MTT (3-(4,5Dimethylthiazol-2-yl)-2,5-diphenyltetrazolium bromide) solution was added and the cells were further incubated at $37^{\circ} \mathrm{C}$ for $4 \mathrm{~h}$. The absorbance was read at a wavelength of $570 \mathrm{~nm}$ and analyzed using Calcusyn software (BIOSOFT, Cambridge, UK).

Quantitative real-time PCR ( $q R T-P C R)$ analysis. Total RNA was extracted from the cells using TRIzol reagent (Invitrogen, Carlsbad, CA, USA) according to the manufacturer's instruction. The reverse transcription reaction was performed with $2 \mu \mathrm{g}$ of RNA and oligo (dT). The newly synthesized cDNA was amplified on a Stratagene Mx3005P system (Stratagene, La Jolla, CA, USA) using a QuantiTect SYBR Green PCR kit (Qiagen, Valencia, CA, USA). Primers specific for CK2 $\alpha$, CK2 $\alpha$ ' and GAPDH were designed as follows: CK2 $\alpha$ forward 5'-TGT CCG AGT TGC TTC CCG ATA CTT-3' and reverse 5' -TTG CCA GCA TAC AAC CCA AAC TCC3'; CK2 $\alpha$ ' forward 5'-AGC CCA CCA CCG TAT ATC AAA CCT-
3' and reverse 5'-ATG CTT TCT GGG TCG GGA AGA AGT-3'; GAPDH forward 5'-CCA TGG AGA AGG CTG GGG-3' and reverse 5'-CAA AGT TGT CAT GGA TGA CC-3'. Amplification cycles were: $95^{\circ} \mathrm{C}$ for $10 \mathrm{~min}$, then 40 cycles at $95^{\circ} \mathrm{C}$ for $30 \mathrm{sec}$, $60^{\circ} \mathrm{C}$ for $10 \mathrm{sec}$ and $72^{\circ} \mathrm{C}$ for $30 \mathrm{sec}$, followed by $72^{\circ} \mathrm{C}$ for $10 \mathrm{~min}$.

Whole exome sequencing and RNA sequencing data. We used whole exome sequencing (WES) and RNA-seq data which were obtained from the genome database of Songdang Institute for Cancer Research (SICR), Yonsei University College of Medicine (Seoul, Republic of Korea) to analyze gene expression profile in human gastric cancer cell lines. mRNA expression was measured by RNAseq in fragments per kilobase million (FPKM) with normalization following the standard analysis algorithm.

Western blot analysis. Proteins were extracted from gastric cancer cell lines. Total protein $(50 \mu \mathrm{g})$ was separated by SDS-PAGE $(12 \%$ polyacrylamide gel) and transferred to polyvinylidene difluoride (PVDF) membrane. The membrane was incubated in blocking solution consisting of 5\% skim milk in TBST at room temperature for $1 \mathrm{~h}$ before being incubated at $4^{\circ} \mathrm{C}$ overnight with primary antibody specific for CK2 $\alpha$ (anti-CK2 $\alpha$, Santa Cruz Biotechnology, CA, USA). This antibody recognizes both CK2 catalytic subunits $\alpha$ and $\alpha$ '. Peroxidaseconjugated antibody (anti-mouse, Jackson ImmunoResearch, West Baltimore Pike West Grove, PA, USA) was used as secondary antibody. The reagent for the enhanced ECL kit was used for detection and images were taken with X-ray film. Data were normalized to $\alpha$-tubulin levels (anti- $\alpha$-tubulin, St. Louis, MO, USA). Protein expression was analyzed by ImageJ software (NIH, Bethesda, MD, USA).

CK2 activity assay. CK2 activity was determined by using a CK2 activity kit (CycLex ${ }^{\circledR}$ CK2 Kinase Assay) (CycLex, Nagoya, Japan). CK2 containing lysates derived from gastric cell lines were added onto recombinant p53 pre-coated 96-well plates. Then $90 \mu 1$ kinase reaction buffer was added and the samples were incubated at $30{ }^{\circ} \mathrm{C}$ for $30 \mathrm{~min}$. The wells were washed 5 times with washing buffer, $100 \mu \mathrm{l}$ HRP-conjugated Detection Antibody (TK4D4) was added to the wells and the samples were incubated for $30 \mathrm{~min}$ at RT. The wells were washed 5 times with washing buffer again, $100 \mu \mathrm{l}$ substrate reagent was placed into each well and the samples were incubated for $15 \mathrm{~min}$. Then, $100 \mu \mathrm{l}$ stop solution was added and absorbance was analyzed. The absorbance in 96-well plates at dual wavelengths of $450 / 595 \mathrm{~nm}$ was measured. (Sunrise ${ }^{\mathrm{TM}}$ Absorbance Reader, TECAN, Switzerland).

Statistical analysis. Student's $t$-test and one-way Analysis of Variance (ANOVA) were used to analyze the findings of the in vitro assay. A $p$-Value of less than 0.05 was considered statistically significant. Comparisons between groups were performed using the Mann-Whitney $U$-test for continuous variables. Statistical analysis was performed using a SPSS, version 21.0 software (SPSS Inc, Chicago, IL, USA).

\section{Results}

CK2 expression profile and activity in human gastric cancer cell lines. CK $2 \alpha$ and CK2 2 ' mRNA and protein expression and their activity were analyzed in 49 human gastric cancer cell lines. According to profiling, mRNA, protein and activity showed broad range of CK2 status in gastric cancer cell lines 
A
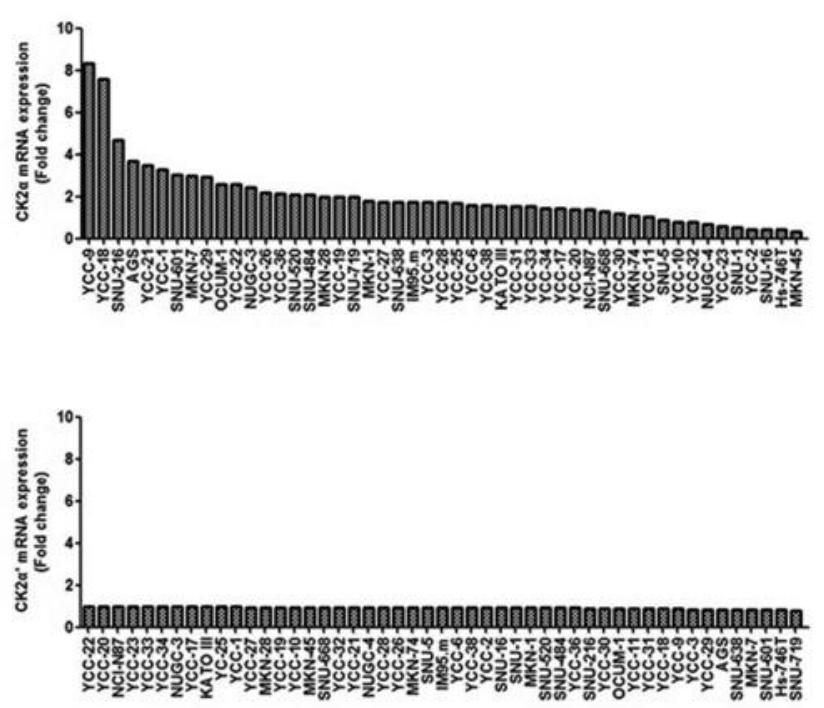

C

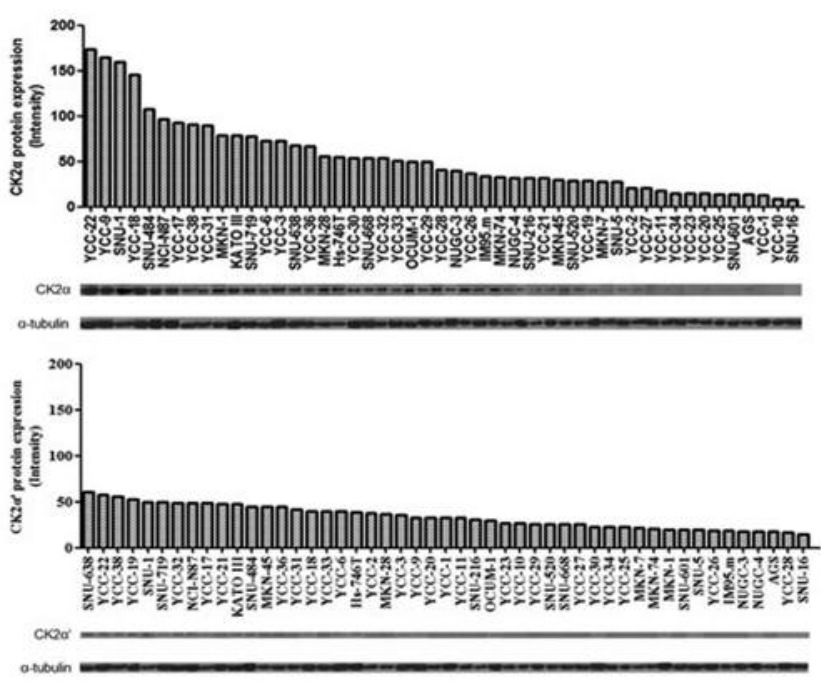

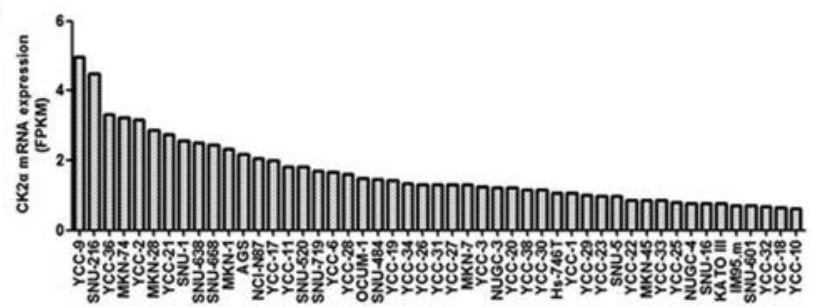

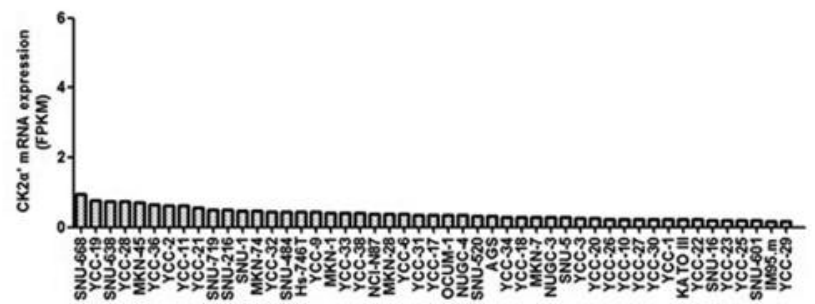

D

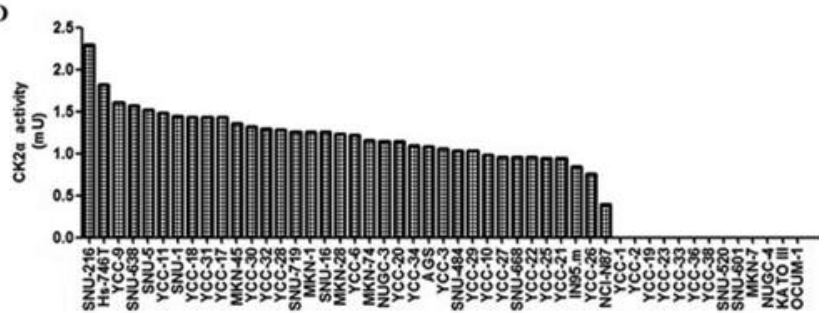

Figure 1. The mRNA and protein expression of CK2, and the activity of CK2 in 49 gastric cancer cell lines. All cell lines align by the order of CK2 expression and CK2 activity. (A) The mRNA expression of CK2 $\alpha$ and CK2 $\alpha$ ' in 49 gastric cancer cell lines was measured using qPCR. (B) The $m R N A$ expression of $C K 2 \alpha$ and $C K 2 \alpha$ ' in 49 gastric cancer cell lines was measured by sequencing. $(C)$ The protein expression of $C K 2 \alpha$ and $C K 2 \alpha$ ' in 49 gastric cancer cell lines. (D) The CK2 $\alpha$ activity in 49 gastric cancer cell lines.

(Figure 1A, B, C and D). Most of the gastric adenocarcinoma cell lines expressed CK $2 \alpha$ protein, but, only a few cell lines expressed CK2 $\alpha$ '. Interestingly, compared to CK2 $\alpha$ that was expressed in a few signet-ring cancer cell lines, CK2 $\alpha$ ' was not expressed in any of them. In both cell types, the CK $2 \alpha$ protein showed a higher expression than CK2 $\alpha$ '. Furthermore, the adenocarcinoma cells expressed higher levels of CK2 $\alpha$ than the signet-ring carcinoma cells (Figure 2A). In qPCR analysis of mRNA expression, YCC-9 and YCC-18 cell lines showed higher $\mathrm{CK} 2 \alpha$ expression than the other cell lines. However, CK2 $\alpha$ ' was expressed at a similar level in all cell lines (Figure 2B). In the mRNA expression sequencing analysis, only YCC-9 cell line highly expressed CK2 $\alpha$ and the two cell types expressed CK2 $\alpha^{\prime}$ minimally (Figure 2C). The CK2 $\alpha$ activity was not detected in a few signet-ring carcinoma cell lines, however, it showed a higher activity in the adenocarcinoma cell lines $(p=0.0108)$. Although CK $2 \alpha$ was not detected in some cell lines, it is possible that they express very low levels (Figure 2D). Comparison of CK2 $\alpha$ and CK2 $\alpha$ ' expression and activity, based on gastric cancer histology, indicated significant variations in protein expression and activity between the two groups 
A

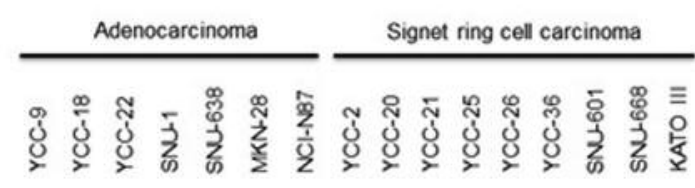

CK2a

$\mathrm{CK} 2 \alpha^{\prime}$

a-tubulin

B
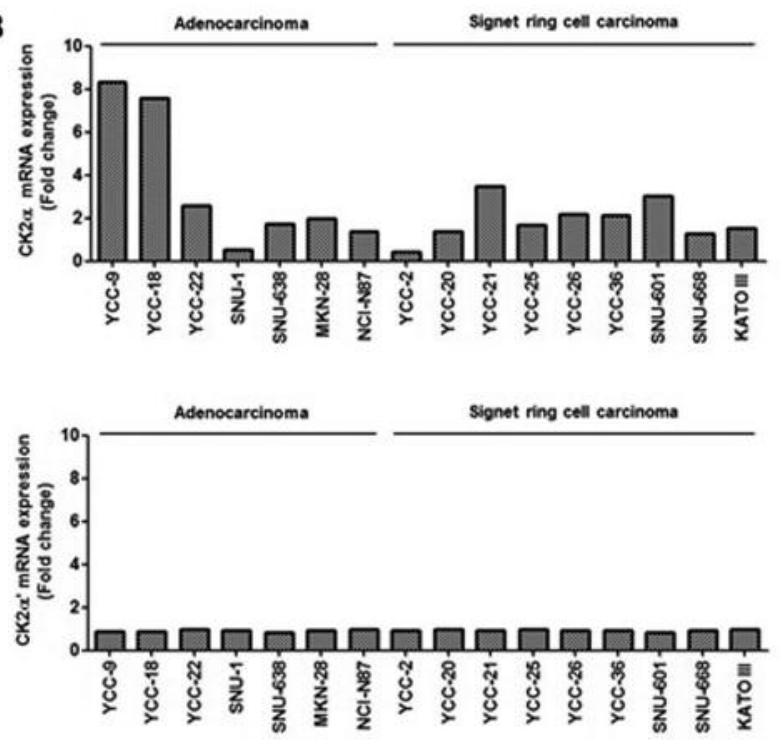

C
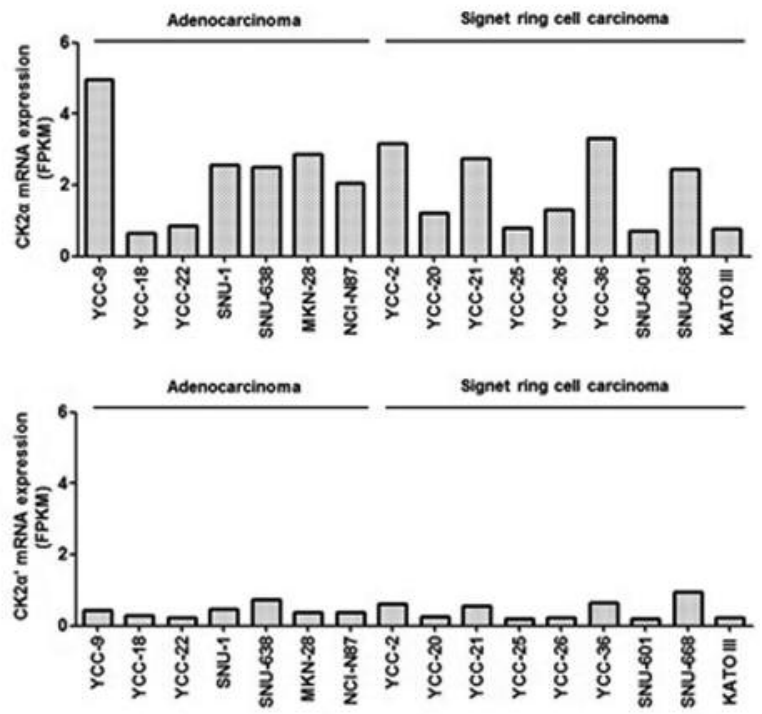

D

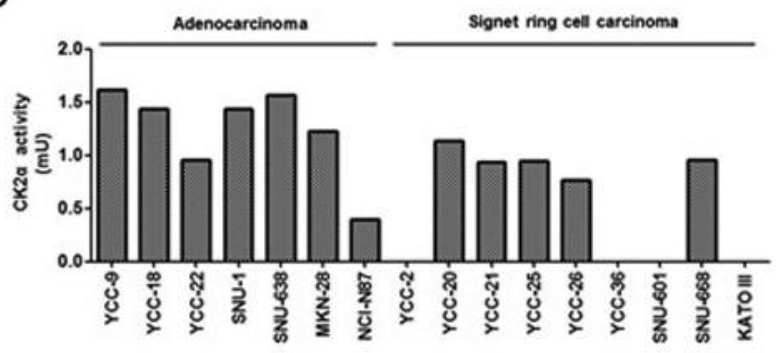

Figure 2. Representative CK2 expression and activity in gastric cancer cell lines. The mRNA and protein expression levels and enzymatic activity of the $C K 2 \alpha$ and $C K 2 \alpha$ ' in the gastric cancer cell lines were determined. Protein kinase CK2 consists of two catalytic subunits, CK2 $\alpha(42 \mathrm{kDa}), C K 2 \alpha$ ' $(38 \mathrm{kDa})$. (A) The protein expression of $C K 2 \alpha$ and $C K 2 \alpha$ ' were determined by western blot analysis. $\alpha$-tubulin was used as a loading control. The expression was classified into two major histological subtypes, adenocarcinoma and signet-ring cell carcinoma. (B, C) The mRNA expression of CK2 $\alpha$ and $C K 2 \alpha$ ' were determined by $q P C R$ and sequencing. (D) The CK2 $\alpha$ activity was measured using a CK2 activity kit (CycLexß CK2 Kinase Assay).

Evaluation of sensitivity to CX-4945 in human gastric cancer cell lines. When sensitivity to CX-4945 was determined by $\mathrm{IC}_{50}, \mathrm{IC}_{50}$ values ranged from $2.74 \mu \mathrm{M}$ to $>20 \mu \mathrm{M}$ (median $=11.27 \mu \mathrm{M}$, with an average $\pm \mathrm{SD}$ of 22.88 $\mu \mathrm{M} \pm 48.13 \mu \mathrm{M})$. The inhibition rate at $10 \mu \mathrm{M}$ ranged from $-1 \%$ to $89 \%$ (median $=41 \%$, with an average \pm SD of $45 \% \pm 22 \%$ ). The cell lines were divided into two groups, sensitive and resistant, with an arbitrary cut-off of $30 \%$ inhibition rate at $10 \mu \mathrm{M}$. Despite the fact that the cut-off value is arbitrary, it can be considerable for a cytostatic agent and $10 \mu \mathrm{M}$ is under Cmax dose $(15 \mu \mathrm{M})$. As a result, 35 cell lines $(71.4 \%)$ were sensitive and 14 cell lines were resistant to CX-4945. Most of the resistant cell lines showed an $\mathrm{IC}_{50}$ greater than $15 \mu \mathrm{M}$, which is the maximum clinically feasible concentration (Figure 3). As a result, inhibition of cell growth by CX-4945 suggested potential antitumor effect in gastric cancer cell lines (Figure 4).

The relationship between $C X-4945$ sensitivity and expression of CK2, and genetic mutations in human gastric cancer cell lines. To identify potential biomarkers to CX-4945 sensitivity, the association of various molecules with CX-4945 sensitivity was examined. According to RNA sequencing data, the CK2 $\alpha$ mRNA expression was not correlated with CX-4945 sensitivity $(\mathrm{r}=0.2075, p=0.1526)$ (Figure 5A). However, the CK2 $\alpha$ ' mRNA expression was correlated with sensitivity to CX-4945. $(\mathrm{r}=0.2810, p=0.0504)$ (Figure 5B). While no correlations were found between sensitivity to CX-4945 and CK2 protein, the 


\section{Sensitivity of CX-4945}

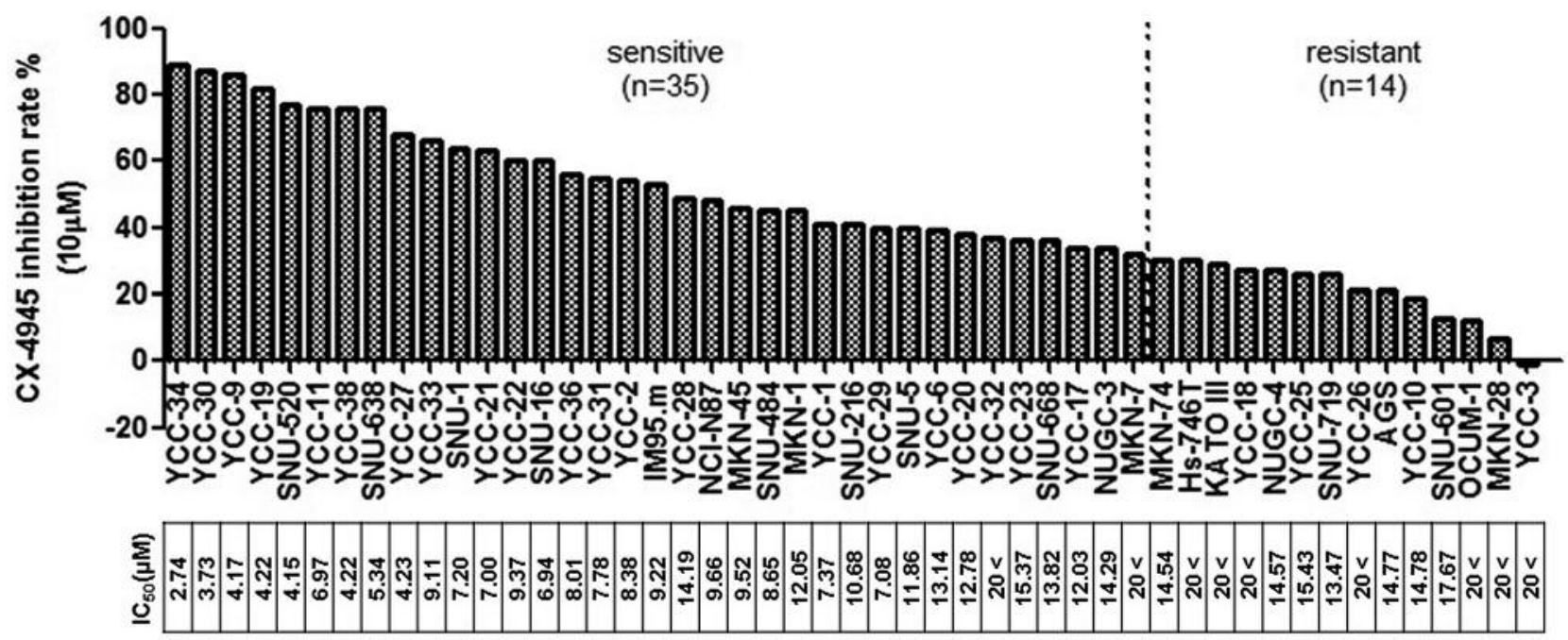

Figure 3. Sensitivity to CX-4945 in gastric cancer cell lines. The $I_{50}$ is from $2.74 \mu M$ to over $20 \mu M$. Sensitivity cut-off was determined over $30 \%$ of inhibition rate in $10 \mu \mathrm{M}$. Sensitive cell lines shows that $I C_{50}$ value was below the $C_{\text {max }}$ dose $(15 \mu M)(n=35)$. On the other side, the cell lines with the inhibition rate under $30 \%$ are resistance to $C X-4945(n=14)$.

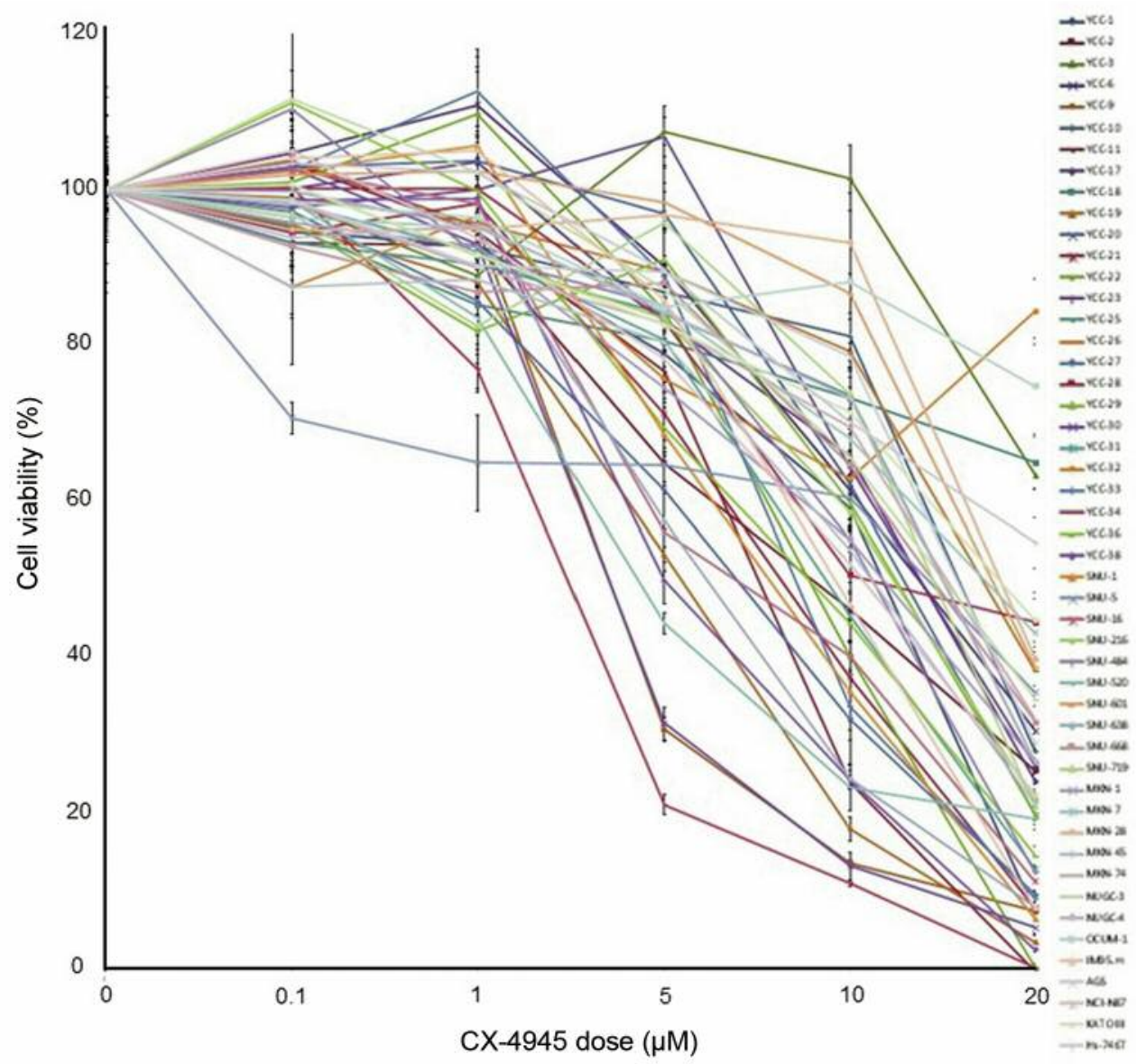

Figure 4. Viability of CX-4945 in 49 gastric cancer cell lines. Cell viability assay was performed using the MTT method. Cell viability was determined after $72 \mathrm{~h}$ of treatment with different $C X-4945$ concentrations. 

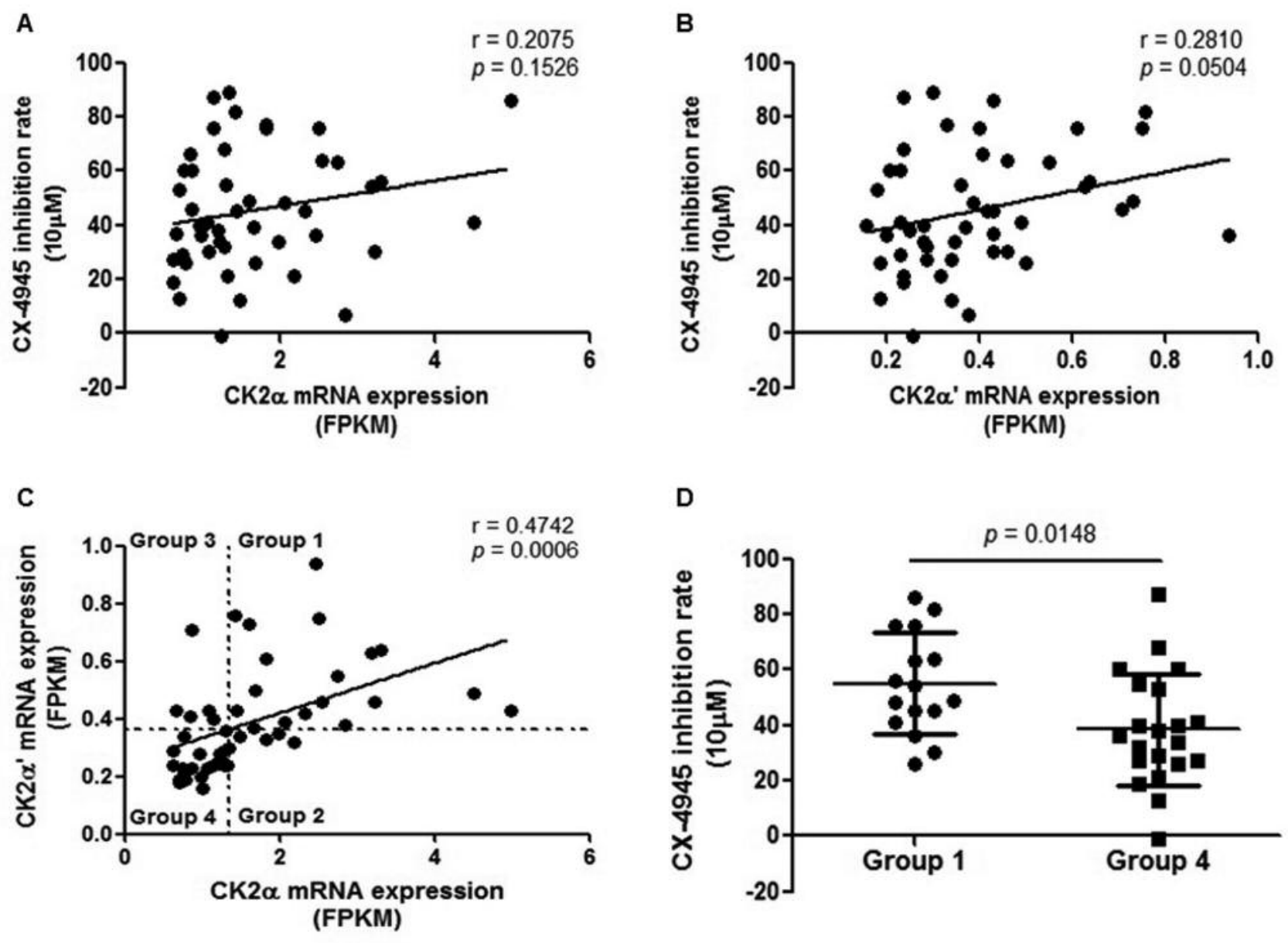

Figure 5. The correlation between CK2 expression and CX-4945 sensitivity. (A) Association between CK2 $\alpha$ mRNA expression and CX-4945 sensitivity. (B) Association between CK2 $\alpha$ ' $m R N A$ expression and $C X-4945$ sensitivity. (C) The cell lines were divided into 4 groups according to cut-off values (median values of CK2 $\alpha$ and CK2 $\alpha$ ' mRNA expression). (D) The correlation between CX-4945 sensitivity and Group 1 (CK2 $\alpha$ and CK2 $\alpha^{\prime}$ high) and Group 4 (CK2 $\alpha$ and CK2 $\alpha^{\prime}$ low).

activity and mRNA expression was determined by qPCR (Figure 6A, B, C). Although our data did not show any clear correlation between sensitivity to CX-4945 and CK2 $\alpha$ expression, the CK2 $\alpha$ expression is usually significantly higher in various tumors. Therefore, we hypothesized that CK2 $\alpha$ expression might play an important role in gastric cancer progression. Further, our data showed a significant correlation between CK $2 \alpha$ and CK2 $\alpha$ ' mRNA expression ( $\mathrm{r}=0.4742$, $p<0.0006$ ) (Figure 5C) suggesting that both CK2 $\alpha$ and CK $2 \alpha$ ' expression levels are important in increasing the sensitivity to CX-4945. Therefore, cell lines were divided into four groups based on CK2 $\alpha$ and CK2 $\alpha^{\prime}$ mRNA expression profile: Group 1 had high expression of CK $2 \alpha$ and CK2 $\alpha^{\prime}$ and Group 4 had low expression of CK2 $\alpha$ and CK2 $2 \alpha^{\prime}$. Group 2 had high expression of only CK2 $\alpha$ and Group 3 had only high expression of CK2 $\alpha^{\prime}$. Also, Group 1 was the most sensitive to
CX-4945 ( $\mathrm{n}=16)$ and Group 4 was the most resistant to CX$4945(n=21)(p=0.0148)$ (Figure 5D). However, the expression of CK2 mRNA, protein and activity were not clearly correlated with sensitivity to CX-4945 (Figure 7).

We also evaluated genetic mutations, which were known to be regulated by CK2. First, we confirmed significant differences in CK2 RNA expression values between group 1 and group $4(p<0.0001)$. As CX-4945 affects not only CK2 $\alpha$ and $\mathrm{CK} 2 \alpha$ ' but also other subunits including C-myc, PI3K, P53/P21, XRCC1 and MDC1, we expected that some of these mutations might interfere with the interaction between CX-4945 and the subunits. Contrary to our expectations, several mutations were found in both groups, but they were not associated with sensitivity to CX-4945. Only CK2 $\alpha$ and CK $2 \alpha$ ' mRNA expression was associated with CX-4945 sensitivity (Figure 8). 

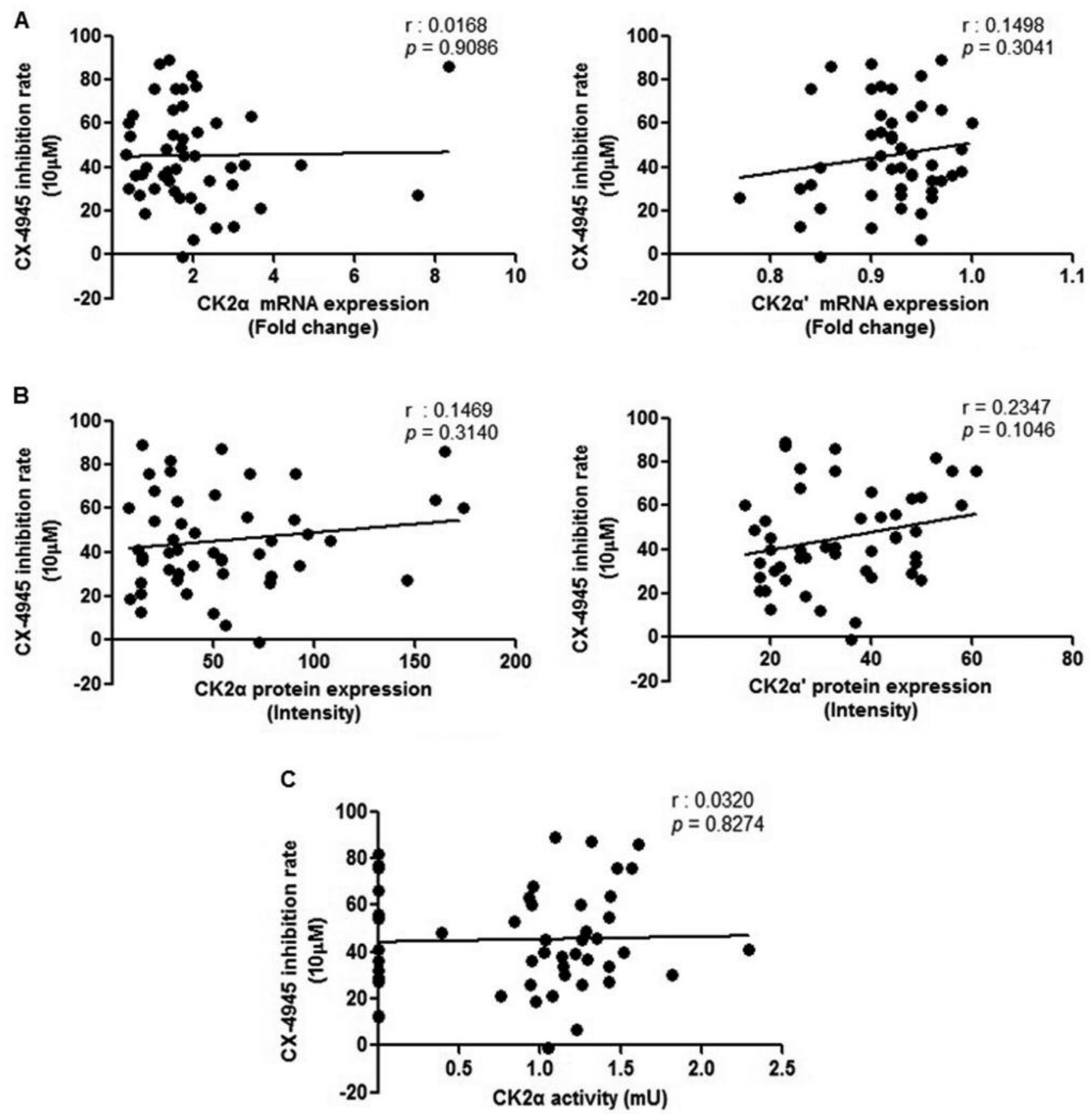

Figure 6. The correlation between the levels of CK2 mRNA and protein, CK2 activity and sensitivity to CX-4945. CK2 mRNA expression was analyzed by $q P C R$. (A) Association between $C K 2 \alpha$ and CK2 $\alpha$ ' mRNA expression and CX-4945 sensitivity. (B) Association between CK2 $\alpha$ and $C K 2 \alpha$ ' protein expression and CX-4945 sensitivity. (C) Association between $C K 2 \alpha$ activity and sensitivity to CX-4945.

\section{Discussion}

CK2 is well known for its role in cell survival and resistance to apoptosis. It is overexpressed in many solid tumors and is associated with poor prognosis. Although many studies revealed the role of $\mathrm{CK} 2$ in other cancers, the precise function of CK2 in gastric cancer is still poorly understood. Moreover, previous studies have shown that $\mathrm{CK} 2 \alpha$ is upregulated in solid tumors, but very little is known about CK $2 \alpha$ '. Our data showed that the CK $2 \alpha$ mRNA and protein are expressed at higher levels compared to $\mathrm{CK} 2 \alpha^{\prime}$ in gastric cancer. The adenocarcinoma and signet-ring cell lines 


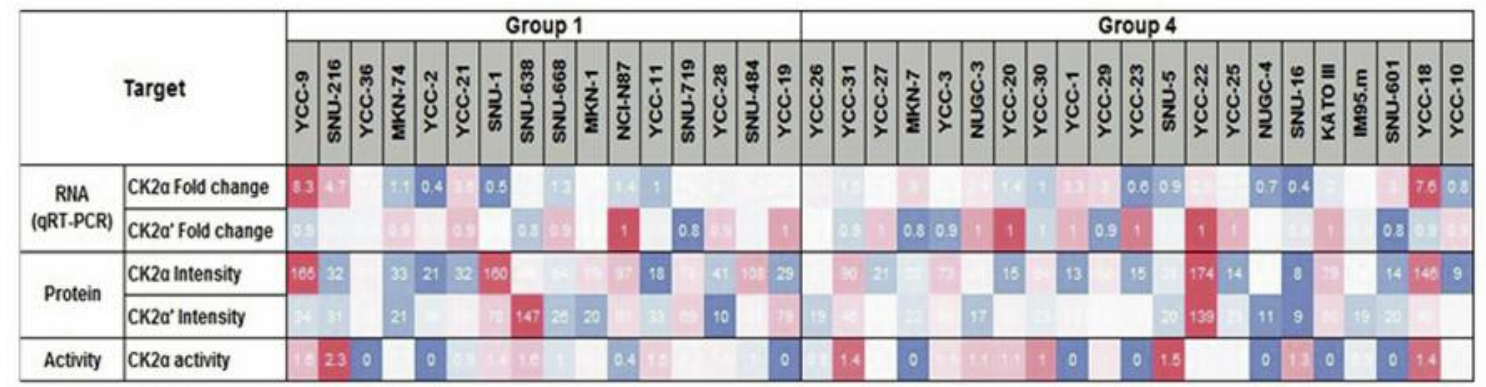

High expression

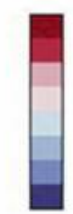

Low expression

Figure 7. Association between CK2 mRNA and protein expression, activity and sensitivity to CX-4945. Analysis of CK2 mRNA expression by qPCR. Group 1: high mRNA expression of both CK2 $\alpha$ and CK2 $\alpha$ ' and classified as the CX-4945 sensitive group. Group 4: low mRNA expression of both $C K 2 \alpha$ and CK2 $\alpha$ ' and classified as the least sensitive group to CX-4945. Association between CK2 $\alpha$ and CK2 $\alpha^{\prime}$ mRNA, protein expression and CK2 $\alpha$ activity in both groups 1 and 4 .

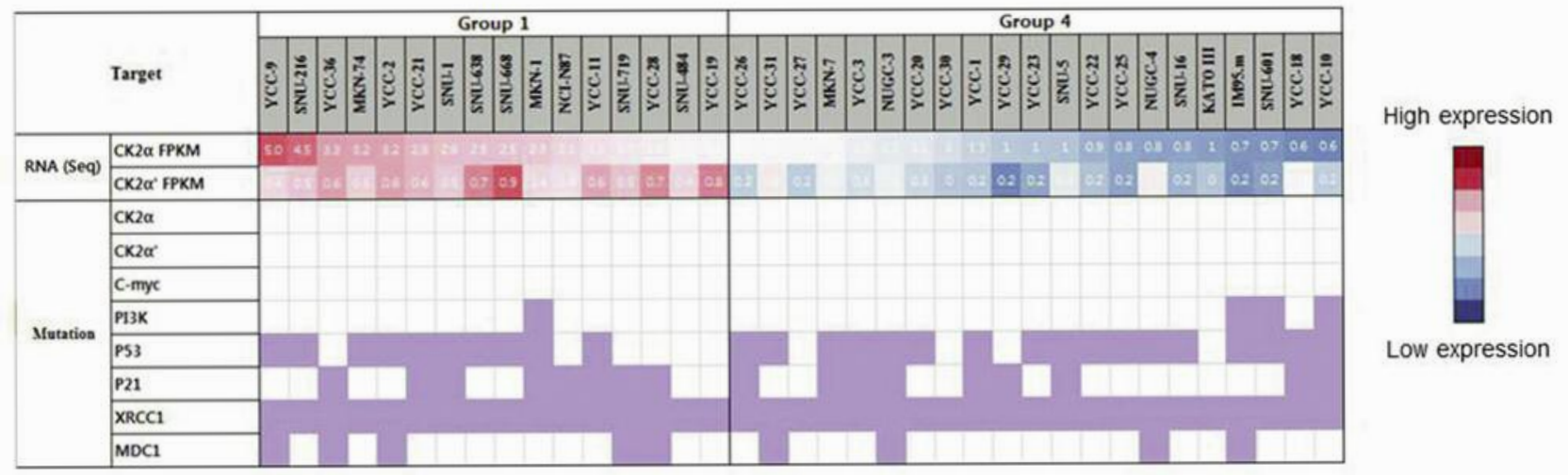

Figure 8. The CX-4945-sensitive group demonstrated high CK2 mRNA expression, not relevant to genetic variations. Comparing CK2 $\alpha$ and CK2 $\alpha$ ' $m R N A$ expression in the 2 groups, by RNA sequencing: Group 1 (sensitive group) showed higher mRNA expression of CK2 $\alpha$ and CK2 $\alpha$ ' compared to Group 4 (resistant group). Genetic variations are designated by the purple boxes.

expressed CK2 $\alpha$ protein, but the signet-ring cells did not express CK2 $\alpha$ '. Furthermore, patients with adenocarcinoma had significantly higher CK2 $\alpha$ activity than those with signet-ring cell carcinoma. These observations suggest that CK2 $\alpha$ might play an important role in the pathogenesis and progression of gastric adenocarcinoma.

CX-4945 is a potent and selective inhibitor of CK2 and is now being investigated in a phase $\mathrm{I} / \mathrm{II}$ clinical trial (ClinicalTrials.gov Identifier: NCT02128282) for cancer therapy. Our results showed that most gastric cancer cell lines where sensitive to CX-4945. The sensitive cell lines showed lower $\mathrm{IC}_{50}$ values at clinically-relevant concentrations. Furthermore, these cell lines were inhibited by least $30 \%$ following treatment with $10 \mu \mathrm{M}$. CX-4945 is a cytostatic agent with a minimum inhibition rate of only $30 \%$ against CK2 $\alpha$ and $\mathrm{CK} 2 \alpha$ '. These sensitivity data are also correlated with CK2 sequence profiling. CX-4945 sensitivity is associated with a higher mRNA expression of both CK $2 \alpha$ and CK2 $\alpha$ '. However, there is no correlation between the drug sensitivity and the protein; same as between enzymatic activity and drug sensitivity. Therefore, both CK $2 \alpha$ and CK2 $\alpha$ ' mRNA may play an important role in CX-4945 efficacy in gastric cancer cell lines.

Genetic profiling showed normal CK2 function in gastric cancer cell lines, because all cell lines have wild-type CK2 $\alpha$ and CK2 $\alpha$ '. Generally, the CK2 substrate plays an important role in solid tumor development including gastric cancer. In addition, gene mutations increase the severity of cancer and are associated with a poor prognosis. However, in our gastric cancer cell line, C-myc was not overexpressed in both sensitive and resistant groups. PI $3 K$ mutations are observed in one cell line in the sensitive group and in few cell lines in the resistant group, however, $X R C C 1$ mutations were expressed in all the cell lines. Mutations in the p53/p21 and 
MDC1 genes were also expressed in both groups. Although group 1 was more sensitive to CX-4945, these was no significant difference with Group 4 (the least sensitive group) in terms of genetic mutations. The mutation status was not associated with sensitivity to CX-4945. These results suggest that the different mutations found in gastric cancer cell lines affect the sensitivity to CX-4945, which may not depend on CK2 substrate mutations.

In conclusion, many targeted therapies are under investigation for gastric cancer. Furthermore, the increase in the number of potential drug targets increases treatment options. Novel and better therapeutic targets and targeted agents are essential to improve the outcomes of gastric cancer with increased efficacy and limited side-effects. Our study suggests that CK2 mRNA expression represents a potential therapeutic target in gastric cancer, thus, the development of CX-4945 might be a promising therapeutic agent against gastric cancer.

\section{Acknowledgements}

This research was supported by Basic Science Research Program through the National Research Foundation of Korea (NRF) funded by the Ministry of Science, ICT \& Future Planning (2017R1A2B2005772) and a grant of the Korea Health Technology R\&D Project through the Korea Health Industry Development Institute (KHIDI), funded by the Ministry of Health \& Welfare, Republic of Korea (HI13C2096).

\section{References}

1 Suh M, Choi KS, Park B, Lee YY, Jun JK, Lee DH and Kim Y: Trends in Cancer Screening Rates among Korean Men and Women: Results of the Korean National Cancer Screening Survey, 2004-2013. Cancer Res Treat 48(1): 1-10, 2016.

2 Jung KW, Won YJ, Kong HJ and Lee ES: Prediction of Cancer Incidence and Mortality in Korea, 2018. Cancer Res Treat 50(2): 317-323, 2018.

3 Luo G, Zhang Y, Guo P, Wang L, Huang Y and Li K: Global patterns and trends in stomach cancer incidence: Age, period and birth cohort analysis. Int J Cancer 141(7): 1333-1344, 2017

4 Park SC and Chun HJ: Chemotherapy for advanced gastric cancer: review and update of current practices. Gut Liver 7(4): 385-393, 2013.

5 Lee JH, Kim JG, Jung HK, Kim JH, Jeong WK, Jeon TJ, Kim JM, Kim YI, Ryu KW, Kong SH, Kim HI, Jung HY, Kim YS, Zang DY, Cho JY, Park JO, Lim DH, Jung ES, Ahn HS and Kim HJ: Clinical practice guidelines for gastric cancer in Korea: an evidence-based approach. J Gastric Cancer 14(2): 87-104, 2014.

6 Ang YL, Yong WP and Tan P: Translating gastric cancer genomics into targeted therapies. Crit Rev Oncol Hematol 100: 141-146, 2016.

7 Gunturu KS, Woo Y, Beaubier N, Remotti HE and Saif MW: Gastric cancer and trastuzumab: first biologic therapy in gastric cancer. Ther Adv Med Oncol 5(2): 143-151, 2013.

$8 \mathrm{Xu} \mathrm{W}$, Yang Z and $\mathrm{Lu} \mathrm{N}$ : Molecular targeted therapy for the treatment of gastric cancer. J Exp Clin Cancer Res 35(1): 1, 2016
9 Montenarh M: Protein kinase CK2 in DNA damage and repair. Transl Cancer Res 5(1): 49-63, 2016.

10 Pierre F, Chua PC, O'Brien SE, Siddiqui-Jain A, Bourbon P, Haddach M, Michaux J, Nagasawa J, Schwaebe MK, Stefan E, Vialettes A, Whitten JP, Chen TK, Darjania L, Stansfield R, Bliesath J, Drygin D, Ho C, Omori M, Proffitt C, Streiner N, Rice WG, Ryckman DM and Anderes K: Pre-clinical characterization of CX-4945, a potent and selective small molecule inhibitor of CK2 for the treatment of cancer. Mol Cell Biochem 356(1-2): 37-43, 2011.

11 Bliesath J, Huser N, Omori M, Bunag D, Proffitt C, Streiner N, Ho C, Siddiqui-Jain A, O’Brien SE, Lim JKC, Ryckman DM, Anderes K, Rice WG and Drygin D: Combined inhibition of EGFR and CK2 augments the attenuation of PI3K-Akt-mTOR signaling and the killing of cancer cells. Cancer Let 322(1): 113$118,2012$.

12 So KS, Rho JK, Choi YJ, Kim SY, Choi CM, Chun YJ and Lee JC: AKT/mTOR down-regulation by CX-4945, a CK2 inhibitor, promotes apoptosis in chemorefractory non-small cell lung cancer cells. Anticancer Res 35(3): 1537-1542, 2015.

13 Zou J, Luo H, Zeng Q, Dong Z, Wu D and Liu L: Protein kinase CK $2 \alpha$ is overexpressed in colorectal cancer and modulates cell proliferation and invasion via regulating EMT-related genes. J Transl Med 9(1): 97, 2011.

14 Lin KY, Tai C, Hsu JC, Li CF, Fang CL, Lai HC, Hseu YC, Lin YF and Uen YH: Overexpression of nuclear protein kinase CK2 alpha catalytic subunit (CK2alpha) as a poor prognosticator in human colorectal cancer. PLoS One 6(2): e17193, 2011.

15 Zhang HX, Jiang SS, Zhang XF, Zhou ZQ, Pan QZ, Chen CL, Zhao JJ, Tang Y, Xia JC and Weng DS: Protein kinase CK2alpha catalytic subunit is overexpressed and serves as an unfavorable prognostic marker in primary hepatocellular carcinoma. Oncotarget 6(33): 34800-34817, 2015.

$16 \mathrm{Xu}$ W, Chen Q, Wang Q, Sun Y, Wang S, Li A, Xu S, Roe OD, Wang M, Zhang R, Yang L and Zhou J: JWA reverses cisplatin resistance via the CK2-XRCC1 pathway in human gastric cancer cells. Cell Death Dis 5: e1551, 2014.

17 Bae JS, Park SH, Kim KM, Kwon KS, Kim CY, Lee HK, Park BH, Park HS, Lee H, Moon WS, Chung MJ, Sylvester KG and Jang KY: CK2alpha phosphorylates DBC1 and is involved in the progression of gastric carcinoma and predicts poor survival of gastric carcinoma patients. Int J Cancer 136(4): 797-809, 2015.

$18 \mathrm{Kim} \mathrm{J}$ and Kim SH: Druggability of the CK2 inhibitor CX-4945 as anticancer drug and beyond. Arch Pharm Res 35(8): 12931296, 2012.

19 Siddiqui-Jain A, Drygin D, Streiner N, Chua P, Pierre F, O'Brien SE, Bliesath J, Omori M, Huser N, Ho C, Proffitt C, Schwaebe MK, Ryckman DM, Rice WG and Anderes K: CX4945 , an orally bioavailable selective inhibitor of protein kinase CK2, inhibits prosurvival and angiogenic signaling and exhibits antitumor efficacy. Cancer Res 70(24): 10288-10298, 2010.

20 Siddiqui-Jain A, Bliesath J, Macalino D, Omori M, Huser N, Streiner N, Ho CB, Anderes K, Proffitt C, O'Brien SE, Lim JK, Von Hoff DD, Ryckman DM, Rice WG and Drygin D: CK2 inhibitor CX-4945 suppresses DNA repair response triggered by DNA-targeted anticancer drugs and augments efficacy: mechanistic rationale for drug combination therapy. Mol Cancer Ther 11(4): 994-1005, 2012. 
21 Chon HJ, Bae KJ, Lee Y and Kim J: The casein kinase 2 inhibitor, CX-4945, as an anti-cancer drug in treatment of human hematological malignancies. Front Pharmacol 6: 70, 2015.

22 Qamra A, Xing M, Padmanabhan N, Kwok JJT, Zhang S, Xu C, Leong YS, Lee Lim AP, Tang Q, Ooi WF, Suling Lin J, Nandi T, Yao X, Ong X, Lee M, Tay ST, Keng ATL, Gondo Santoso E, Ng CCY, Ng A, Jusakul A, Smoot D, Ashktorab H, Rha SY, Yeoh KG, Peng Yong W, Chow PKH, Chan WH, Ong HS, Soo KC, Kim KM, Wong WK, Rozen SG, Teh BT, Kappei D, Lee J, Connolly J and Tan P: Epigenomic promoter alterations amplify gene isoform and immunogenic diversity in gastric adenocarcinoma. Cancer Discov 7(6): 630-651, 2017.
23 Kim C, Yang H, Park I, Chon HJ, Kim JH, Kwon WS, Lee WS, Kim TS and Rha SY: Rho GTPase RhoJ is associated with gastric cancer progression and metastasis. J Cancer 7(11): 15501556, 2016.
Received October 1, 2018

Revised October 12, 2018

Accepted October 15, 2018 